Journal of Bangladesh Academy of Sciences, Vol. 38, No. 1, 71-74, 2014

\title{
MORPHOMETRIC AND MERISTIC ANALYSIS OF COILIA RAMCARATI (HAMILTON, 1822) FOR RACIAL INVESTIGATION FROM CHITTAGONG AND COX'S BAZAR COASTS
}

\author{
MD. SOHEL PARVEZ AND MD. RASHED-UN-NABI ${ }^{1}$ \\ Department of Oceanography, University of Dhaka, Dhaka-1000, Bangladesh
}

\begin{abstract}
Morphometric measurements and meristic counts of Coilia ramcarati (Hamilton, 1822) were analysed statistically to ascertain the possible racial difference in the species from Chittagong and Cox's Bazar coasts of the Bay of Bengal. Some variations were found (insignificant, $p \geq 0.05$ ), indicating that the populations of $C$. ramcarati from Chittagong and Cox's Bazar coasts are not racially differentiated.
\end{abstract}

Key words: Coilia, Morphometric analysis, Correlation matrix

\section{INTRODUCTION}

The Coilia ramcarati (Hamilton, 1822) is a member of the family Engraulidae (Anchovies), commonly known as "Tapper tail anchovy" or "Frill-tailed golden anchovy" locally called "Olua" in Bangladesh (Rahman and Akhter 2009). It is a schooling species distributed in the Indian Ocean, Arabian sea and South China sea (Whitehead et al. 1968), with a tropical climate range of $25^{\circ} \mathrm{N}-13^{\circ} \mathrm{N}, 87^{\circ} \mathrm{E}-97^{\circ} \mathrm{E}$. The species has also been reported from Ganges delta and Andaman Sea south of Rangoon (Talwar and Jhingran 1991) and Sundarbans mangrove forest (Debnath 2001). It is highly relished either as fresh or dried and commands a high market value from other species of this genus. Morphometric and meristic studies have provided useful results for identification of marine fish stocks describing their spatial distribution (Ihssen et al. 1981) and is the first step in investigating the stock structure of species with large population sizes (Motomura et al. 2007). Species identification and population discrimination are important in the conservation of biodiversity, natural resources and fisheries management (Ibañez et al. 2007). Identifying intraspecific units or stocks of a species with unique morphological characters enables a better management of these subunits of species and ensures perpetuations of the resources (Jaferian et al. 2010). Information on morphometric and meristic features as well as length-weight patterns is necessary for assessment of the fishery to ensure sustainability and for their inclusion in a regional food security programme (Akin-Oriola et al. 2005). Though this species is contributing a notable share, about 0.12 to $2.25 \%$ of in the artisanal fishery of Bangladesh (Nabi 2007), a very few reports are available on the taxonomy and biology of the $C$.

\footnotetext{
${ }^{1}$ Institute of Marine Sciences and Fisheries, University of Chittagong, Chittagong-4331, Bangladesh.
} 
ramcarati. Hence, the present study was carried out to observe the racial differentiation of the species through the analysis of morphometric and meristic characteristics.

\section{MATERIALS AND METHOD}

Collia ramcarati is available in the entire coast of Bangladesh from southwestern Khulna region to southeastern Cox's bazar region with fluctuating distribution (Rahman and Akhter 2009, Kamal and Khan 2009). From the initial field survey it was found that the maximum catch of $C$. ramcarati is landed in Chittagong and Cox's Bazar regions of Bangladesh. Fish sample was collected monthly from the landing centers and local markets of the Chittagong and Cox's Bazar coast of the Bay of Bengal during January to December, 2010. Samples were transported to the laboratory and thawed in a bucket of cold water. After complete thawing linear measurements and counts of different variables were taken turning the head left with a measuring scale and calipers to the nearest centimeter $(0.00 \mathrm{~cm})$. The gill rakers of the anterior gill arch were counted using magnifying glass after removal of the anterior gill arch from the fish. All the morphometric measurements were transformed to $\log _{10}$ because linearity and normality are usually more closely approximated by logarithms than by original variables (Hair et al. 1998). Log transformed measurements were tested using the one-way ANOVA to observe the differences in allometric relationships among the samples both within and between these two stations.

\section{RESULTS AND DISCUSSION}

The morphometric measurements included total length (TL), standard length (SL), pre-dorsal length (PDL), head length (HL), eye diameter (ED), post-orbital length of head (POLH), inter orbital width (IOW), snout length (SNL) and body depth (BD) of the specimens. Morphometric measurements are given in Table 1.

Table 1. Morphometric measurements of $C$. ramcarati from Chittagong and Cox's Bazar.

\begin{tabular}{|c|c|c|c|c|c|c|c|c|}
\hline \multirow{3}{*}{ Parameters } & \multicolumn{4}{|c|}{ Chittagong, $(\mathrm{N}=24)$} & \multicolumn{4}{|c|}{ Cox's Bazar, $(\mathrm{N}=24)$} \\
\hline & \multicolumn{2}{|c|}{ Range } & \multirow{2}{*}{$\begin{array}{c}\text { Mean } \pm \text { Std. } \\
\text { error }\end{array}$} & \multirow{2}{*}{$\begin{array}{c}\text { Percentage } \\
\text { of TL }\end{array}$} & \multicolumn{2}{|c|}{ Range } & \multirow{2}{*}{$\begin{array}{c}\text { Mean } \pm \text { Std. } \\
\text { error }\end{array}$} & \multirow{2}{*}{$\begin{array}{c}\text { Percentage } \\
\text { of TL }\end{array}$} \\
\hline & Min. & Max. & & & Min. & Max. & & \\
\hline TL & 13.70 & 18.70 & $16.48 \pm 0.24$ & ------ & 13.82 & 19.64 & $17.20 \pm 0.26$ & ------ \\
\hline SL & 13.00 & 18.10 & $15.34 \pm 0.26$ & 93.08 & 12.84 & 18.82 & $15.86 \pm 0.26$ & 92.21 \\
\hline PDL & 3.80 & 5.50 & $4.47 \pm 0.09$ & 27.12 & 3.77 & 5.61 & $4.55 \pm 0.09$ & 26.45 \\
\hline HL & 2.00 & 3.50 & $2.82 \pm 0.06$ & 17.11 & 2.50 & 3.54 & $2.90 \pm 0.04$ & 16.86 \\
\hline ED & 0.50 & 0.60 & $0.55 \pm 0.01$ & 3.34 & 0.49 & 0.60 & $0.56 \pm 0.01$ & 3.26 \\
\hline POLH & 1.60 & 3.00 & $1.89 \pm 0.05$ & 11.47 & 1.62 & 3.01 & $1.91 \pm 0.05$ & 11.10 \\
\hline IOW & 0.80 & 1.10 & $0.93 \pm 0.02$ & 5.64 & 0.78 & 1.10 & $0.95 \pm 0.02$ & 5.52 \\
\hline SNL & 0.50 & 1.10 & $0.69 \pm 0.03$ & 4.19 & 0.50 & 1.11 & $0.70 \pm 0.03$ & 4.07 \\
\hline $\mathrm{BD}$ & 1.50 & 3.50 & $2.58 \pm 0.10$ & 15.66 & 1.53 & 3.55 & $2.59 \pm 0.09$ & 15.06 \\
\hline
\end{tabular}

The meristic counts were done for branchiostegal rays (Br), dorsal fin (D) spines and rays, pectoral fin (P) filaments, spines and rays, pelvic fin (V) spines, anal fin (A) spine 
and rays, gill rakers (Gr), lateral transverse (L.tr.), and scutes were recorded for the specimens. The meristic characters of the species showed approximately the same results for each specimen except in some minor cases, from the present study from which the taxonomic formula obtained is: $B r$ xii; D iii.13-14; P 6+5-7; V i.8-10; A ii.90; L.tr.10; Scutes 10+5; Gr.30.

Each of the other 8 morphometric characters showed a linear relationship with the $\mathrm{TL}$ when analysed by sample (all regressions were significant at $\mathrm{p} \leq 0.01$ ). The other 6 morphometric characters showed a linear relationship with SL except BD. There was significant linear relationship of PDL with HL, IOW, SNL and BD. Both the IOW and SNL are correlated with HL. No other morphometric characters were found correlated with ED, POLH and IOW except that with the TL only BD correlated with SNL.

In Chittagong region no significant differences were observed $(p>0.05)$ for the TL, SL, PDL, HL, ED, POLH, IOW and SNL except for the BD $(p<0.05)$ from the analysed fish samples. While in Cox's Bazar region significant differences were observed $(p<0.05)$ for the SNL and BD of the analysed specimens and all the other morphometric variables showed no significant differences ( $\mathrm{p} \geq 0.05$ ). Moreover, when all the morphometric characters were tested between two regions no significant differences were observed ( $\leq 0.05$ ). The morphometric measurements among the populations of $C$. ramcarati from Chittagong and Cox's Bazar coasts showed some variations within samples. Cheng et al. (2005) also detected morphometric distinctness among the genus Coilia samples and suggested that a direct relationship between the extent of morphometric divergence and geographic separation. However, the variations observed in the present study were not significantly different $(\mathrm{p}<0.05)$. The significance of the difference is appraised by means of statistical procedures based on the theory of probability, it is usually extremely difficult to determine whether differences are phenotypic or genotypic, yet knowledge of the causes of the differences is essential to understand the significance. The geographical locations of the experimental stations and the different environmental conditions between them are not same. Habitat, temperature, elevation, slope gradient, stream velocity, productivity, sex and age exerted profound impact on these characters (Hubbs 1926, Barlow 1961, Hempel and Blexter 1963, Hopkirk 1973, Kirka 1974). Hence, the observed differences within stations, in this investigation are probably due to the variations in geography, ecology and human activities in the regions. These suggest that the fish populations of $C$. ramcarati from the experimental stations were not separable taxonomically. They may not be genetically separable populations but statistically separable.

\section{ACKNOWLEDGEMENT}

The investigation was supported by 'The National Science Information and Communication Technology (NSICT) Fellowship', 2010-2011, (Economic Code No. 32605-3965-5901), awarded by the Ministry of Science Information and Communication Technology, Government of Bangladesh. 


\section{REFERENCES}

Akin-Oriola, G., M. Anetekhai and K. Olowonirejuaro. 2005. Morphometric and Meristic Studies in Two Crabs: Cardiosoma armatum and Callinectes pallidus. Turkish Journal of Fisheries and Aquatic Sciences 5: 85-89.

Barlow, G. W. 1961. Causes and significance of morphological variation in fishes. Systematic Zoology 10:105-117.

Cheng, Q. Q., Lu, D. R. and M, Li. 2005. Morphological differences between close populations discernible by multivariate analysis: A case study of genus Coilia (Teleostei: Clupeiforms). Aquat. Living Resour. 18: 187-192.

Debnath, H. S. 2001. Sunderbans Biosphere Reserve, Biosphere Reserve Information Service (BRIS), State of Art Report, Ministry of Environment and Forest, Government of India, New Delhi.

Hair, J. F. Jr., R. E. Anderson, R. L. Tatham and W. C. Black. 1998. Multivariate Data Analysis. $5^{\text {th }}$ edition, Prentice-Hall, Upper Saddle River, USA.

Hempel, G. and J. H. S. Blexter. 1963. Experimental modification of meristic characters in herring (Clupea harengus L). Journal Counseil. 26:336-346.

Hopkirk, J. D. 1973. Endemism in fishes of the dear lake region of central California. Univ. California Publ. Zool. 96: 1-135.

Hubbs, C. L. 1926. The structure consequences of modifications of the development rate in fishes considered in reference to certain problems of evaluation. The American Naturalist 60: 57-81.

Ibañez, A. L., I. G. Cowx and P. O'Higgins. 2007. Geometric morphometric analysis of fish scales for identifying genera, species, and local populations within the Mugilidae. Canadian Journal of Fisheries and Aquatic Sciences 64: 1091-1100.

Ihssen, P. E., H. E. Booke, J. M. Casselmen, J. M. McGlade, N. R. Payne and F. M. Utter. 1981. Stock identification: materials and methods. Can. J. Fisheries and Aquatic Sciences 38: 18381855.

Jaferian, A., H. Zolgharnein, M. Mohammadi, M. Salari-Aliabadi and S. Hossini. 2010. Morphometric Study of Eleutheronema tetradactylum in Persian Gulf Based on The truss Network. World J. Fish and Marine Sciences 2(6): 499-504.

Kamal, A. H. M. and M. A. A. Khan. 2009. Coastal and estuarine resources of Bangladesh: management and conservation issues. Maejo International J. Science and Technology 3(2): 313-342.

Kirka, A. 1974. Variation in somatic characters of the brown trout (Salmo trutta fario L) in the head water of the Poprad river (High Tatra Mts). Zoologik Listy. 23: 85-94.

Motomura, H., Y. Iwatsuki, S. Kimura and T. Yoshino. 2007. Revision of the Indo-West Pacific polynemid fish genus Eleutheronema. Fish Base 41639: 12-16.

Nabi, M. R. 2007. Management of Estuarine Set Bag Net Fishery of Bangladesh: Application of Traditionl Scientific Methods, Sustainable Livelihoods Approach and Local Indigenous Knowledge (Ph.D. Thesis), Borneo Marine Research Institute, University Malaysia Sabah. pp. 240.

Rahman, M. K. and J. N. Akhter. 2009. Ichthyodiversity in the Rivers and Estuaries of Khulna Division, Bangladesh. J. Taxonomy and Biodiversity Research 3: 19-27.

Talwar, P. K. and A. G. Jhingran. 1991. Inland Fishes of India and Adjacent Countries (Vol-1). Oxford and IBH Publishing Co. Pvt. Ltd., New Delhi. pp. 126-131.

Whitehead, P. J. P., G. J. Nelson and T. Wongratana. 1968. Coilia ramcarati (Hamilton, 1822), Ramcarat grenadier anchovy, Available from: http://www.cbd.int/2010/welcome/Accessed on $7^{\text {th }}$ April 2011). 